Working Paper No. 576, 2002

Exchange-Rate and Interest-Rate Driven Competitive Advantages in the EMU

by Niclas Andrén and Lars Oxelheim

IUI, The Research Institute of Industrial Economics

P.O. Box 5501

SE-114 85 Stockholm

Sweden 


\title{
Exchange-Rate and Interest-Rate Driven Competitive Advantages in the EMU
}

\author{
Niclas Andrén \\ Department of Business Administration, Lund University \\ PO Box 7080, SE-220 07 Lund, Sweden \\ Phone: +46-46-222 4666 \\ Fax: +46-46-222 4437 \\ Email: niclas.andren@fek.lu.se

\section{Lars Oxelheim} \\ Institute of Economic Research, Lund University \\ PO Box 7080, SE-220 07 Lund, Sweden \\ Phone: +46-46-222 8744 \\ Fax: +46-46-222 4437 \\ Email: lars.oxelheim@fek.lu.se \\ and \\ The Research Institute of Industrial Economics \\ PO Box 5501, SE-114 85 Stockholm, Sweden \\ Phone: +46-8-665 4527 \\ Fax: +46-8-665 4599 \\ Email: 1arso@iui.se
}

March 12, 2002

\begin{abstract}
Real exchange and interest rates may still fluctuate inside the EMU and give rise to changes in competitiveness. We find, in contrast to what is generally expected, no convergence in these variables after the introduction of the euro. On the contrary, a divergence is found that is extraordinary when compared to the preceding 40 years. The magnitude of the divergence should urge on a wave of restructuring in the EMU, conditioned upon adequate policy responses. The worst-case scenario involves a flight to structural support and protectionism, challenging the whole idea of the EMU.
\end{abstract}

Keywords: Real exchange rates, real interest rates, EMU, competitive advantage, restructuring.

JEL classifications: E31, E44, F15, F23, G34 


\section{Exchange-Rate and Interest-Rate Driven}

\section{Competitive Advantages in the EMU}

Introduction

An important objective of the EU on the road towards increased welfare for its citizens is to eliminate barriers to competition between its member countries by increasing the transparency in cross-border transactions. An important argument behind the creation of the single market was that it would eliminate legal trade barriers. Similarly, an important idea behind the introduction of the euro was that it would eliminate macroeconomic trade barriers, or as expressed by the European Commission (2001) in an ex-post review of the EMU, "[t]he euro is a crucial component to the single market as it fosters competition and eliminates harmful exchange- and interest-rate friction" (ibid:8).

Put another way, by introducing a common currency the macroeconomic prerequisites for competition between companies and countries were supposed to become equalized. The underlying argument is intuitive: the existence of multiple currencies allows companies to price discriminate by having different sales prices in different countries. Introducing a common currency eliminates buyers' - end consumers' as well as corporate buyers' difficulties with comparing prices expressed in different currencies.

The "Cost of Non-Europe" report (Emerson, 1988) evaluated the potential benefits of introducing the single market. It argued that abolishing all trade barriers within the EU could lead to GNP increases in the EU in the range of $4.5 \%$ to $6.5 \%$. The upper limit would result if all price discrimination were eliminated within the EU. Experience has shown that the single market so far has not eliminated all price discrimination (European Commission, 1996 and 1999). Gros and Thygesen (1998) instead argued that the introduction of the euro could be the 
catalyst that eliminates the remaining price discrimination. The value of the euro could then amount to the difference in the range suggested by the "Cost of Non-Europe" report, or as much as $2 \%$ of the GNP of the EMU.

Baldwin $(1989 ;$ 1991) criticized estimations of the value of elimination of price discrimination following the introduction of a common currency to be too conservative. His argument was that such calculations only consider non-recurrent effects, such as elimination of transaction costs. Baldwin instead argued that dynamic growth effects must be considered. He maintained that such effects could arise, since the euro could be assumed to result in a low, stable, and common level of inflation in Euro land, thereby lowering the cost of capital. This would strongly promote economic growth. Furthermore, increased price transparency and competition could be expected to lead to companies rationalizing and increasing productivity. Productivity increases could have large long-term growth effects and could lead to further GNP increases in Euro land.

It is too soon to evaluate any long-term dynamic growth effects of the euro. However, it is not too soon to evaluate where we are heading in terms of any effects of the euro on competitiveness. If the euro were to live up to expectations in bringing about elimination of macroeconomic trade barriers, then macroeconomically driven competitiveness would be eliminated. Leveling of competitive conditions would then force companies to rationalize as suggested by Baldwin. The influence of the euro on corporate competitiveness is determined by how it affects corporate relative prices and risk exposures. In this paper the influence of the euro on relative prices in Euro land is studied, both between the countries in Euro land and relative to those EU countries that do not belong to the EMU.

The focus here is on the influence of the euro on exchange-rate driven and interest-rate driven competitive advantages in the manufacturing sector. Our founding assumption is that if the euro were to bring about convergence in macroeconomic relative prices and/or 
convergence in levels of macroeconomic risk, then the result would be reduced importance of macroeconomically driven competitive advantages. Converging real exchange and interest rates would lead to reductions in exchange- and interest-rate driven competitive advantages. If the euro were the prime driver of real exchange- and interest-rate convergence, then countries outside Euro land would not exhibit the same convergence patterns.

The real exchange rate is a commonly used measure of competitiveness for internationally competing firms, due to its direct influence on relative factor and production costs as well as on sales prices. The real interest rate is not as commonly used a competitiveness measure. Nevertheless, real interest rates influence both factor costs and demand levels, making them important macroeconomic influences on corporate competitiveness. Much focus is on consumer prices. For example the European Central Bank (ECB) targets consumer prices and the Stability and Growth Pact is aimed at avoiding divergences in consumer prices among the countries in Euro land. The choice of price measure is important to the conclusions drawn on the influence of the euro on competitiveness. Evaluations of real exchange and interest rates are sometimes also based on consumer or wholesale prices as measures of inflation. However, neither consumer nor wholesale prices capture the cost and price structures of most manufacturing firms, which make them less relevant in an investigation of cross-border competitiveness. Here we instead use producer prices, labor costs, and interest rates to approximate corporate cost and price structures. Our interest lies in the cost and price developments in the manufacturing sector.

We are particularly interested in the extremes when it comes to the development of real exchange and interest rates. The extremes determine the strains put by the euro on corporate competitiveness and on the well being of the EMU. This means that we focus on the dispersion of real exchange- and interest-rate developments in Euro land rather than on the average developments. 
Previous ex-post evaluations of the euro have not focused much on the impact of the euro on corporate competitiveness. Ex-post evaluations of the euro have in particular focused on the developments of the value of the euro relative to the dollar and the yen (see, for example, the European Commission, 2001; Eichengreen, 2000; Feldstein, 2000). Both Feldstein (2000) and the European Commission (2001) note inflation differentials within Euro land, but only discuss consumer prices and do not delve deeper into their potential consequences for competitiveness. Feldstein (2000) concluded that EMU obviously not is an optimal currency area, observing that demand conditions deviated among member countries, with some countries experiencing relatively weak demand, whereas others experienced very strong demand. The result was as expected, as noted by Feldstein, namely substantial acceleration of consumer-price inflation in countries with strong demand.

The rest of the paper has the following outline. Initially, we discuss the theoretical relationships among exchange, interest, and inflation rates. The relationships motivate our evaluation of the competitive effects of the macroeconomic convergence in Euro land. Then follows a section motivating why exchange, interest, and inflation rates are important to corporate profitability and competitiveness. As an introduction to our evaluation of the effects of the euro on competitiveness so far, we present our methodology and the monetary history of the EU. Thereafter the empirical analysis is presented in four sections. The first two sections deal with exchange-rate driven competitive advantages and evaluate convergence in real exchange rates in Euro land and the rest of the EU. Then follows a section on labor costs in the EU. The empirical analysis is rounded off with an evaluation of convergence in real interest rates in the EU. We conclude by summarizing our results and discussing their policy implications. 


\section{The impact of the macro economy on competitiveness}

Economics and management teach that a firm can be competitive by having market power that allows it to secure and protect a strong market position, by having better finances through lower average costs, higher productivity, unique factors of production, or by being more innovative than its competition. Exchange and interest rates could, in particular, affect a firm's competitiveness by influencing its cost position. The impacts of exchange and interest rates on cost competitiveness are captured by two relationships, namely purchasing power parity and the real interest rate parity. Under complete economic and financial integration, both relationships would be in equilibrium (Oxelheim, 1996).

\section{Exchange rates and competitiveness}

Exchange-rate changes could be a source of exchange-rate-driven competitive advantages for a country and its firms, since relative price levels in different currencies, when expressed in the same currency, are determined by the exchange rate. The introduction of the euro means that all prices in Euro land now are expressed in the same currency. In this respect the euro thus eliminates problems of comparing prices in different currencies. However, it is not the nominal exchange rate, but the real, inflation adjusted exchange rate that matters to corporate competitiveness.

Purchasing power parity states that changes in the nominal exchange rate between two currencies should be approximately equal to the difference in inflation between the two countries. If not, the real exchange rate will change. An appreciation of the real value of the domestic currency, which could result from an appreciation of the nominal value of the domestic currency or domestic inflation being higher than foreign inflation, is unfavorable for the cost positions of domestic firms. On the other hand, if the inflation in a country is stable, which it tends to be if monetary policy targets inflation, a depreciation of the domestic 
currency will be favorable for domestic producers. The introduction of the euro eliminated changes in nominal exchange rates, but not changes in the real exchange rates. In Euro land, differences in inflation will create cost advantages for those companies experiencing the smallest changes in production costs.

The sensitivities to macroeconomic changes vary among firms, partly as a result of different cost structures. Close competitors could therefore be affected differently by one and the same macroeconomic change. This means that even under complete macroeconomic convergence of price levels, macroeconomically generated differences in competitiveness remain. Therefore on the firm level the impact of the euro on production costs may vary among firms due to differences in cost structures. Andrén (2001) investigated how the sensitivities of the market values of European firms to macroeconomic changes were affected by the introduction of the euro. He found that firms' sensitivities to, in particular, exchangerate changes converged after the introduction of the euro relative to the years prior to the introduction. Such convergence in sensitivities leads to firms being affected more similarly by the same macroeconomic changes. This, in turn, increases the importance of macroeconomic convergence to corporate competitiveness.

\section{Interest rates and competitiveness}

Interest-rate differences among countries could be a source of interest-rate-driven competitive advantages for a country and its firms, since the costs for firms' and consumers' borrowing to a large extent is determined by the domestic interest rates. The introduction of the euro means that all interest rates in Euro land now are expressed in the same currency. Also in this respect the euro eliminates problems of comparing prices in different currencies. However, it is not the nominal interest rate, but the real, inflation adjusted interest rate that matters to corporate competitiveness. If there are deviations from real interest rate parity, 
stating that expected real interest rates on similar loans or investments in two different countries should be the same, then firms with their financing (investments) in countries with low real interest rates will be at a relative cost advantage (disadvantage). Similarly, firms with a majority of their sales in countries with low interest rates will probably have a revenue advantage, due to higher sales as a result of lower real interest rates.

Except for differences in creditworthiness and political risk, the introduction of the euro eliminated differences in nominal interest rates in Euro land, but not differences in real interest rates. In Euro land, differences in inflation will create cost advantages for those companies experiencing the smallest changes in production costs. High-inflation countries will experience lower cost of restructuring. As for exchange rates, on the firm level it is necessary to recognize that the cost of capital could vary among firms due to differences in capital structures.

To summarize, from a competitiveness point of view it is not the introduction of a common currency that is of main interest. Instead, it is the possible convergence in real economic development that this common currency could result in that is of concern. If the introduction of the euro leads to increased economic convergence, then purchasing power parity and real interest rate parity should hold to a greater extent and the real exchange rate be stabilized. Only if the introduction of the common currency contributes to leveling real exchange and interest rates in Euro land will exchange- and interest-rate-driven changes in competitiveness be eliminated.

\section{Channels of macroeconomic influence on the competitiveness of the individual firm}

Before we turn to the empirical investigation, we give a short summary of the channels of macroeconomic influence on the competitiveness of the individual firm. We do not

investigate the impact of changes in the macro economy on the individual firm in the 
empirical investigation, but it is important to remember how macroeconomic changes could influence individual firms when drawing implications from the empirical investigation.

Typically, channels of macroeconomic influence can be divided into three groups,

- influences on sales prices and volumes,

- influences on production costs, and

- influences on wealth.

\section{Influences on sales prices and volumes}

Exporters gain from real depreciations of the domestic currency (DC), since exports priced in this currency will be cheaper in foreign currency (FC). This gives exporters the possibility to increase their DC export prices or let their FC prices fall and thereby increase sales. In reality, most firms follow the strategy of keeping FC prices fairly - but not completely - stable (Knetter, 1993; Goldberg and Knetter, 1997). This results in exporters' DC profit margins, sales volumes, and profitability increasing when the real DC depreciates. Importers instead gain from real DC appreciations, since this means that their costs tend to fall.

Inflation can affect the purchasing patterns of consumers, to the extent that inflation affects the real values of consumers' wages, savings, and debts. Any such effects would, in turn, lead to changes in sales volumes. If wages are indexed to inflation and real interest rates and asset values are independent of inflation, then the effect of inflation on demand would be small. If, on the other hand, wages are not fully indexed or asset values and real interest rates are sensitive to changes in inflation, then inflation will affect demand.

\section{Influences on production costs}

A weak (depreciating) DC that is not accompanied by higher inflation means that DC costs fall relative to production costs in other countries when expressed in the same currency. 
This increases the competitiveness of firms producing in the weak currency by giving them cost advantages. Firms in high-cost countries could, if applicable, exercise the option to move production to countries with undervalued currencies. Studies of the relationship between location of production and exchange-rate changes have shown that this is a strategy that is used by many firms (Ekström, 1998).

Inflation affects the firm's production costs. If the firm is unable to pass through price increases to its sales prices without loss of demand, inflation will be costly. The effect of price

increases on demand is, as noted, linked to the indexation of wages. Real interest rates also affect production costs, since increasing real interest rates mean increasing costs of (real and financial) capital for the firm. Increasing real interest rates are particularly problematic, since they affect firms and consumers in the same way, making it difficult to pass through increases in real interest rates to sales prices.

\section{Influences on wealth}

A firm with assets in FC will find that the value of those assets increases when the DC depreciates. At the same time the values of domestic assets fall when converted to FC, which makes it cheaper for foreign firms to acquire domestic firms after DC depreciation. Increases in inflation lead to falling values of fixed-rate debts in DC, and so do values of fixed-rate assets. Firms with loans and investments at floating rates will not experience these effects.

\section{Methodological and institutional considerations}

For the analysis, benchmarks are required to allow conclusions to be drawn about the influence of the euro on real exchange and interest rates. For this reason, comparisons are made both intertemporally and with countries outside Euro land. Intertemporally, we compare the developments in real exchange and interest rates since the introduction of the euro with the developments in the period from 1960 until the introduction of the euro. The choice of 
starting point in our comparative period is motivated by the countries in Western Europe having striven for monetary integration at least since the European Community was founded in 1958, and that many countries had currency controls after WW2 and full convertibility among the currencies in Central and Western Europe was not introduced until 1958/59. Ever since then different groups of countries, with the founding member of the EU in the center have striven for monetary integration. The introduction of the euro means that this long process has been completed.

An evaluation of real economic convergence due to the introduction of the euro requires three decisions. Firstly, real economic convergence is measured in terms of how exchange and interest rates have developed adjusted for differences in inflation. Here, specifications of how inflation is measured must be made. Secondly, convergence in real exchange rates is a process in relation to a point of reference. This point of reference must be specified. Thirdly, an acceptable weighting system for construction of exchange, interest, and inflation rates for Euro land is required.

As was mentioned earlier, it is developments in producer prices that are the relevant price measures for our study of international cost competitiveness of the manufacturing industry. Our primary measure of inflation is, accordingly, changes in producer prices for the manufacturing industry (defined as ISIC revision 3, industry category D). To be completely comparable, the composition of producer price indices in different countries should be harmonized so as to measure price developments in the same goods and services. Unfortunately, harmonized producer price indices do not exist, which means that the indices we use are not completely comparable across countries. This should be kept in mind when interpreting the results. Still, the indices provide indications of major tendencies in cost developments in the manufacturing industry. As a complement, we also investigate developments of hourly compensation costs. For many firms, and in particular in labor- 
intensive production, developments in labor costs are more accurate measures of cost competitiveness than a general measure of producer prices in the manufacturing industry.

Measures of real exchange rates require specification of a point in time when the real exchange rate could be assumed to have been at parity. Unfortunately, this is a difficult undertaking, in particular when inflation is measured with producer prices. Instead of trying to estimate parity exchange rates, we take as our point of departure the political unity about the reference rates of the euro as a signal of belief in parity. The predecessor of the ECB, the European Monetary Institute, in March 1998 published a report where the convergence criteria stipulated in the Treaty on Economic and Monetary Union (the Maastricht Treaty) as well as other economic indicators were evaluated. The period investigated in the convergence report was February 1997 to January 1998 and based on the conclusions of that report, the governments of Euro land accepted to fix their exchange rates from January 1, 1999. Thereby, the governments signaled that they considered any departures from purchasing power parity to be small enough to disregard. Also, the possibilities of exchange-rate changes were ample before the introduction of the euro due to the wide fluctuation margins in the European Exchange-Rate Mechanism. Still, the exchange rates in Euro land remained stable, which signals that the actors of the foreign-exchange markets also considered the exchange rates to be close to equilibrium.

To conclude the parity issue, we use the average exchange rates over the period February 1997 to January 1998 as parity exchange rates of the euro currencies. The choice of parity for those EU countries not participating in the EMU (Denmark, Greece, Sweden, and the UK) is not as evident. ${ }^{1}$ For comparative reasons, we choose to use the same period to define parity exchange rates for Denmark, Sweden, and the UK. For Greece, we instead use

1 Throughout, we treat Greece as a non-member of the EMU, since Greece did not become a member until January 2001. 
the period April 1999 to March 2000, since this was the reference period in the convergence report published by ECB in May 2000 that was the basis for the decision to accept Greece as a member of the EMU.

Our third decision concerns the choice of weights when aggregating the exchange, interest, and inflation rates of the members of Euro land into measures for Euro land as an entity. The euro and euro interest rates have only existed since January 1999, whereas we need data back to January 1960. This data must be constructed. We calculate hypothetical exchange, interest, and inflation rates for Euro land prior to the introduction of the euro, using the weights the eleven founding members of the EMU had in the construction of the euro on January 1, 1999. This choice of weights is not evident; Beyer, Doornik, and Hendry (2001) instead argued in favor of using adjustable weights. Adjustable weights, with readjustment for example once a year, have the advantage of mirroring changes in the economic importance or well being of different countries in the weighting. The disadvantage is that an adjustment mechanism must be selected. Beyer et al (ibid) suggest using real GDP as weights, whereas the ECB uses private consumption expenditures. Neither accord with the weights the founding members of the EMU had in the euro on January 1, 1999. We choose euro weights, since they reflect the composition of Euro land.

As one piece of evidence on the importance - or lack of importance, as it were - of the choice of weights, we calculated the value of the ECU vis-à-vis our derived euro. The composition of the ECU has differed from the composition of the EMU; for example, the UK was included in the ECU, but is not a member of the EMU. Still, the hypothetical exchange rate between the ECU and our derived euro has been close to one over long periods. ${ }^{2}$

\footnotetext{
2 These results are available from the authors upon request.
} 


\section{Institutional framework of the euro}

We analyze convergence in real exchange and interest rates in the EMU over January 1960 to June 2001. The EU countries exhibit a diverse monetary history. Austria, Belgium, Denmark, France, Germany, Ireland, and the Netherlands have accompanied each other, though with several discrete exchange-rate adjustments along the way. Finland, Greece, Portugal, Spain, Sweden, and the UK have instead followed their own paths. Roughly, five periods with distinct monetary arrangements can be identified, with the breakdown of the Bretton Woods agreement, the introduction of the European Monetary System (EMS), the ERM crisis, and the introduction of the euro as divisors.

During the 1960s, all EU countries participated in the Bretton Woods agreement with fixed exchange rates vis-à-vis the dollar. After the collapse of the Bretton Woods agreement in 1973 the EU countries chose different solutions for their currencies. France, Italy, Spain, and the UK chose floating exchange rates, while Ireland chose to tie the punt to the British pound. Greece and Portugal initially chose to fix their currencies to the dollar, but in the mid1970s switched to other systems; Greece chose a floating exchange rate and Portugal a crawling peg with gradual devaluation according to a predetermined schedule. Belgium, Denmark, Germany, Luxembourg, the Netherlands, and Sweden chose, together with a few other countries, to participate in a fixed-rate system called the snake. Ireland, Italy, and the UK participated in the snake for a couple of months, while France participated for two years. Finland instead chose to tie the markka to a trade-weighted basket, a model implemented by Sweden in 1977. Austria chose to tie the schilling to the German mark.

In 1979 the snake was replaced by the EMS. This system was also founded on fixed exchange rates among the participating currencies. Belgium, Denmark, France, Germany, Ireland, Italy, Luxembourg, and the Netherlands founded the EMS. Spain joined in 1989 and the UK a year later. Portugal tied the escudo to EMS in 1990, but did not join until 1992. 
Austria joined in 1995, Finland in 1996, and Greece in 1998. In September 1992 currency speculation hit several EMS currencies, which resulted in several currencies devaluing and Italy and the UK leaving the EMS in favor of floating exchange rates. Italy rejoined during the fall 1996. Finland and Sweden also had to let their currencies float. The ERM crisis also resulted in widening of the variation margins, from $\pm 2,25 \%$ to $\pm 15 \%$.

The Treaty on Economic and Monetary Union was decided upon in December 1991, and entered into force in November 1993. It was not until the treaty had entered into force that the economic convergence stipulated as a requirement for EMU membership reached the top of the priority lists of politicians in the EU. We denote this period the convergence period in the rest of the article.

\section{Real exchange rates in Euro land}

In this section we look at the developments of real exchange rates in Euro land since the euro was introduced relative to the developments prior to that. As was previously mentioned, our interest is in the gap between the extremes.

Figure 1 shows that the spread between most undervalued and most overvalued euro currency, in real terms, have been large for most of the period. The spread did not fall below $10 \%$ until 1996, and only during the reference period was the spread smaller than 5\%. During the 1960s and 1980s the spread remained constantly large, whereas the 1970s, the mid 1980s, and the early and late 1990s were characterized by convergence. The time around the breakdown of the Bretton Woods agreement, 1978-81, and 1993-94 were instead characterized by divergence in the real valuations of the euro currencies. During the first years of the convergence period, from January 1994 to December 1998, real exchange rates converged strongly. 


\section{Figure 1 Relative spread between largest positive and negative deviations from parity exchange rates vis-à-vis the euro during January 1960 to June 2001}

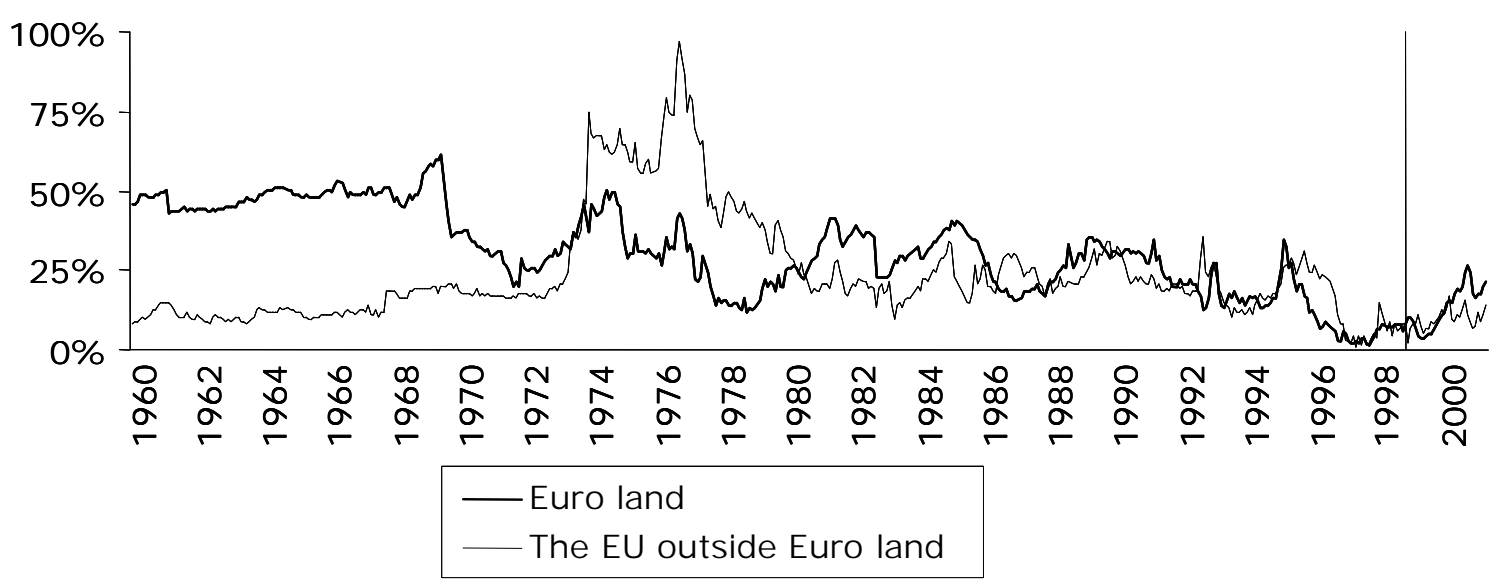

The diagram shows largest relative difference in real exchange rates vis-à-vis the euro for each month between January 1960 and June 2001 for two groups of countries: Euro land and the rest of the EU (Denmark, Greece, Sweden, and the UK). Inflation is measured by monthly changes in producer prices for the manufacturing industry. The real exchange rates were assumed to be at parity in the reference period, February 1997 to January 1998. The vertical line marks the introduction of the euro. Belgium and Luxembourg are included from January 1980, Italy from January 1981, and Portugal from January 1990. Sources: own calculations, International Financial Statistics, and OECD Statistical Compendium.

After the introduction of the euro the spread between most undervalued and most overvalued euro currencies in real terms increased again and was in June 2001 above $21 \%$. Since the exchange rates in Euro land were fixed during the period, this increased spread is entirely a result of divergence in inflation rates in Euro land. The increase in the spread reflects a real depreciation of the franc vis-à-vis the escudo of $30 \%$ due to high (low) inflation in Portugal (France).

Producer-price inflation was generally higher after the introduction of the euro than during the prior convergence period, as is evident from Figure 2. After the introduction the weighted average (using euro weights) producer-price increase in Euro land was $3.5 \%$ per annum compared to $0.7 \%$ per annum in the convergence period, as shown by the horizontal lines in the diagrams. More importantly, the maximum spread in annualized producer-price inflation increased from $2.7 \%$ to $11.0 \%$. Parts of the difference between the two periods can 
be explained by the divergent behavior of producer prices in Portugal. If Portugal is disregarded, then the maximum spread in inflation after the introduction of the euro was 4.8\%. This is still almost twice the maximum spread during the convergence period. Over 30 months, $4.8 \%$ annually means an aggregate difference in price increases of more than 12 percentage points over 30 months. That would be a tough blow to the profitability of any company.

Figure 2 Annualized changes in producer prices during January 1994 to December 1998 (left) and January 1999 to June 2001 (right)

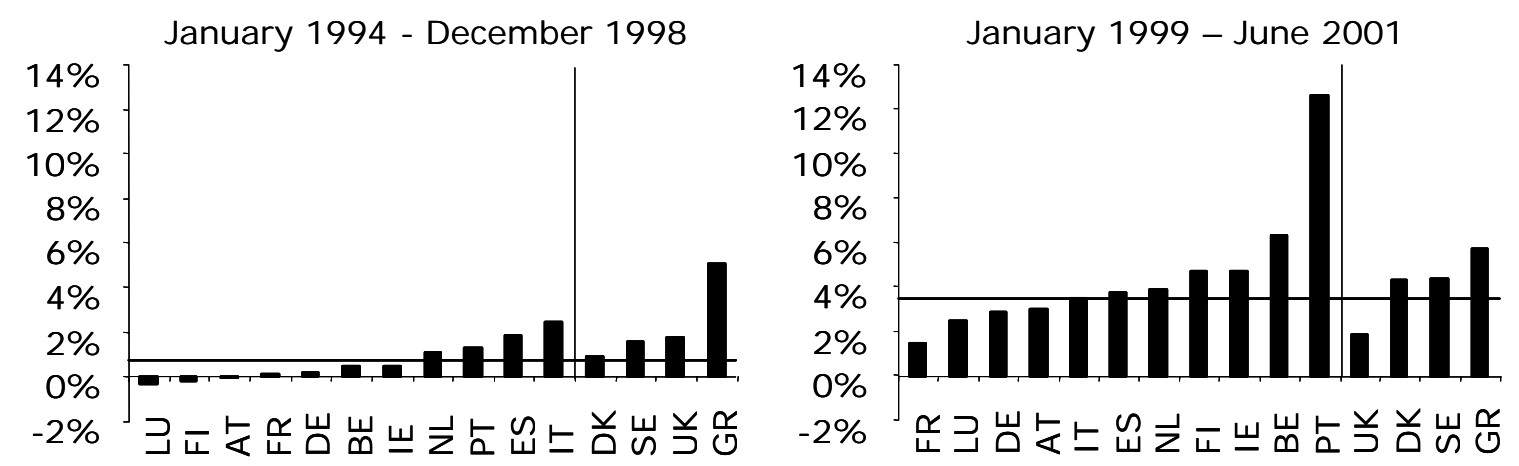

The diagrams show changes in producer prices during January 1994 to December 1998 (left) and January 1999 to June 2001 (right). All inflation rates are annualized to adjust for the difference in length of the two periods. The horizontal lines show the weighted average producer-price changes in Euro land. The vertical lines mark the introduction of the euro. AT: Austria, BE: Belgium, DE: Germany, DK: Denmark, ES: Spain, FI: Finland, FR: France, GR: Greece, IE: Ireland, IT: Italy, LU: Luxembourg, NL: the Netherlands, PT: Portugal, SE: Sweden, and UK: the UK. Sources: own calculations and OECD Statistical Compendium.

What is most striking in Figure 2 is the divergent behavior of Portuguese producer prices after the introduction of the euro. Portuguese producer prices increased by almost $35 \%$ between January 1999 and June 2001. This change rate is double the one in Belgium, which came second, and almost 10 times the rate in France. The effect of this was a real appreciation of the Portuguese escudo in excess of $4 \%$ annually relative to the euro, and as much as by $11 \%$ annually relative to the French franc. 
The real depreciation of the franc vis-à-vis the escudo from the introduction of the euro to June 2001 is exceptional in historical comparison. Figure 3 shows frequency distributions for spreads between largest and smallest changes in producer prices and largest changes in bilateral real exchange rates (differences in changes in real purchasing power) vis-à-vis the euro in Euro land. Inflation and real exchange-rate changes were measured over consecutive 30-month periods (that is, equal to the length of the January 1999 to June 2001 period) for our entire study period and then annualized. ${ }^{3}$ The arrow marked 1999-2001 shows the results for January 1999 to June 2001 (an inflation differential and a real exchange-rate change of $11.0 \%$ annually), while the arrow market 1994-1998 shows the results for January 1994 to December 1998 (an inflation differential of $2.7 \%$ and a real exchange-rate change of $2.4 \%$ ).

As can be seen, most inflation differentials have been smaller than was the case after the introduction of the euro, whereas the opposite holds true for the convergence period. In fact, the spread in inflation between France and Portugal after the euro was introduced belongs to the $16 \%$ largest inflation differentials over the entire 40 -year period investigated. The maximum change in real exchange rates was even more extraordinary; in less than $13 \%$ of all consecutive 30-month periods since January 1960 have bilateral real exchange rates changed more than did the real franc vis-à-vis escudo after the introduction of the euro. These ratios can be compared to the developments during the convergence period. The maximum inflation differential of $2.7 \%$ belongs to the $5 \%$ smallest inflation differentials over the 40 -year period,

\footnotetext{
Inflation differentials were measured as $(1+$ largest percentage change in producer prices in a EMU member over 30 months $) \div(1+$ smallest (or largest negative) percentage change in producer prices in a EMU member over 30 months $)-1$. Largest changes in bilateral real exchange rates were measured as $(1+$ largest percentage change in a country's real exchange rate vis-à-vis the euro over 30 months $) \div(1+$ smallest (or largest negative) percentage change in a country's real exchange rate vis-à-vis the euro over 30 months) - 1.
} 
whereas the maximum change in bilateral real exchange rates of $2.4 \%$ belongs to the $3 \%$ smallest changes.

Figure 3 Relative frequency distributions of largest inflation differentials and changes in bilateral real exchange rates in Euro land during January 1960 to June 2001 (annualized changes over 30 months)

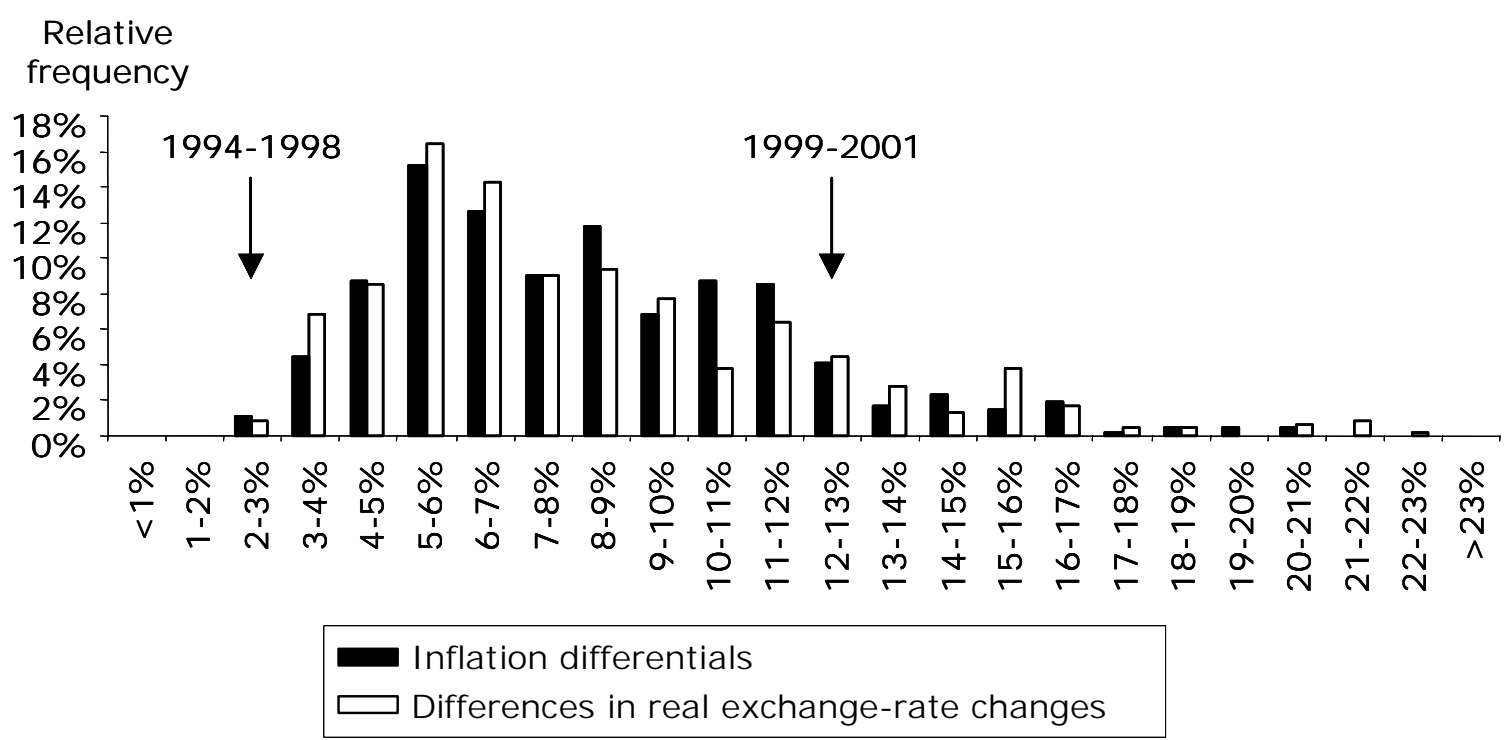

The diagram shows the relative frequencies of largest differences in changes in real exchange rates and largest inflation differentials for each month over January 1960 to June 2001. Changes in real exchange rates and producer prices are measured over consecutive 30-month periods. The arrows mark where the values for the periods January 1994 to December 1998 and January 1999 to June 2001 would fit in. Belgium and Luxembourg are included from January 1980, Italy from January 1981, and Portugal from January 1990. Sources: own calculations, International Financial Statistics, and OECD Statistical Compendium.

To conclude, the Portuguese producer-price and real exchange-rate developments since the introduction of the euro are not unique; however, they are most extraordinary. This conclusion is enhanced by the observation that most large changes in real exchange rates have followed in the wake of larger discontinuities in the foreign-exchange markets and not as a result of large inflation differentials. This was, for example, the case during the breakdown of the Bretton Woods agreement and the ERM crisis. 


\section{Real exchange rates in the rest of the EU}

The dispersion in the real exchange rates of the EU countries outside Euro land partly resembles the one for Euro land (see Figure 1). During the 1960s real exchange rates remained rather stable. This changed during the 1970s, when the dispersion increased as a result of the flotation of the British pound and diverging inflation rates. During the 1980s fluctuations in the real exchange rates were modest in comparison to the 1970s, and there were no trends in the developments. The first half of the 1990s was characterized by diverging real exchange rates, and only late in 1996 did the real exchange rates converge.

The convergence in the real exchange rates in the EU prior to the introduction of the euro came later outside Euro land than inside, but was just as evident. Developments after the introduction also resembled those of Euro land, with increased divergence among the real exchange rates. This divergence was not as marked as in Euro land, however, and the difference in value between the most undervalued and most overvalued currencies was $14 \%$ in June 2001.

The EU countries outside Euro land also exhibited variations in price developments, both before and after the introduction of the euro (see Figure 2). During the convergence period, price changes in Denmark, Sweden, and the UK were equivalent, and also at parity with price changes in Euro land. Greece, on the other hand, experienced large price increases. After the introduction of the euro the UK stood out with small price increases, whereas the other three countries had similar price changes at parity with the changes in those euro countries that exhibited the largest price changes, Portugal disregarded. The EU countries outside Euro land have had one more factor of influence, namely nominal exchange-rate changes. Denmark, Greece, and Sweden only experienced marginal nominal exchange-rate changes after the introduction, ranging between 1-3\% vis-à-vis the euro. The pound, on the 
other hand, appreciated nominally by $14 \%$ vis-à-vis the euro after the introduction up till June $2001 .^{4}$

\section{Labor-cost developments in the EU}

Finally, we make a comparison of hourly compensation costs for production workers in the manufacturing industry. Hourly compensation costs are measured as the sum of hourly direct pay to labor and employer social insurance expenditures and other labor taxes. Figure 4 indicates that the dispersion in hourly compensation costs diverged in Euro land up to the mid-1990s, then converged again up to 1997, and has remained constant since. Nor here do we find any indications of increasing convergence since the introduction of the euro.

Hourly compensation costs in Euro land in the year 2000 were the highest in Germany (about $€ 25$ ), where the hourly compensation costs were almost five times higher than in the country with the lowest costs, Portugal (about €5). This means that German manufacturers paid five times as much as Portuguese manufacturers for the labor. The weighted average hourly compensation cost in Euro land was €20.2 in 2000. Only considering hourly compensation costs, then, Euro land is far from parity. Developments in the rest of the EU mirror those of Euro land, with the exception of converging hourly compensation costs in 1993.

4 Since inflation in the UK was four percentage points below Euro land, the net result was a real appreciation of the pound of $10 \%$. 
Figure 4 Relative spreads between highest and lowest hourly compensation costs for the EU, 1975 to 1999

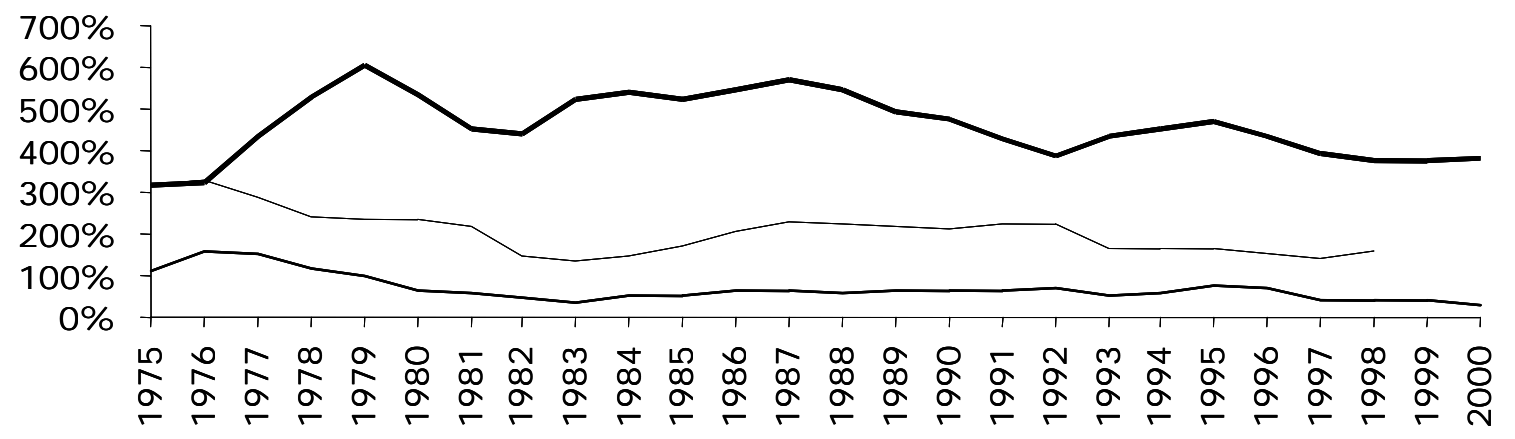

-Euro land

- The EU outside Euro land excl Greece

- The EU outside Euro land incl Greece

The diagram shows relative spreads between highest and lowest hourly compensation costs in euros in Euro land, the rest of the EU (excluding and including Greece). Relative spreads are calculated as the highest hourly compensation cost divided by the lowest. Sources: own calculations and US Bureau of Labor Statistics, Foreign Labor Statistics.

\section{The impact of the euro on convergence in real interest rates}

In this section we study interest-rate driven competitive advantages by analyzing developments in real interest rates. Such an analysis requires specification of both choice of nominal interest rate and choice of inflation measure. We have chosen to study three-month interbank rates and long-term government-bond yields. We are using the change in producer prices over the preceding year as our measure of inflation in a particular month.

Figure 5 shows the developments in differences between highest and lowest threemonth real interest rates in Euro land and in the rest of the EU during January 1980 to June 2001. The time period is shorter than in our other diagrams since money markets were controlled and did not function efficiently in most countries until the late 1970s and the 1980s. The time periods that individual countries are included also vary, for the same reason. 


\section{Figure 5 Differences between highest and lowest short-term real interest rates, January 1980 to June 2001}

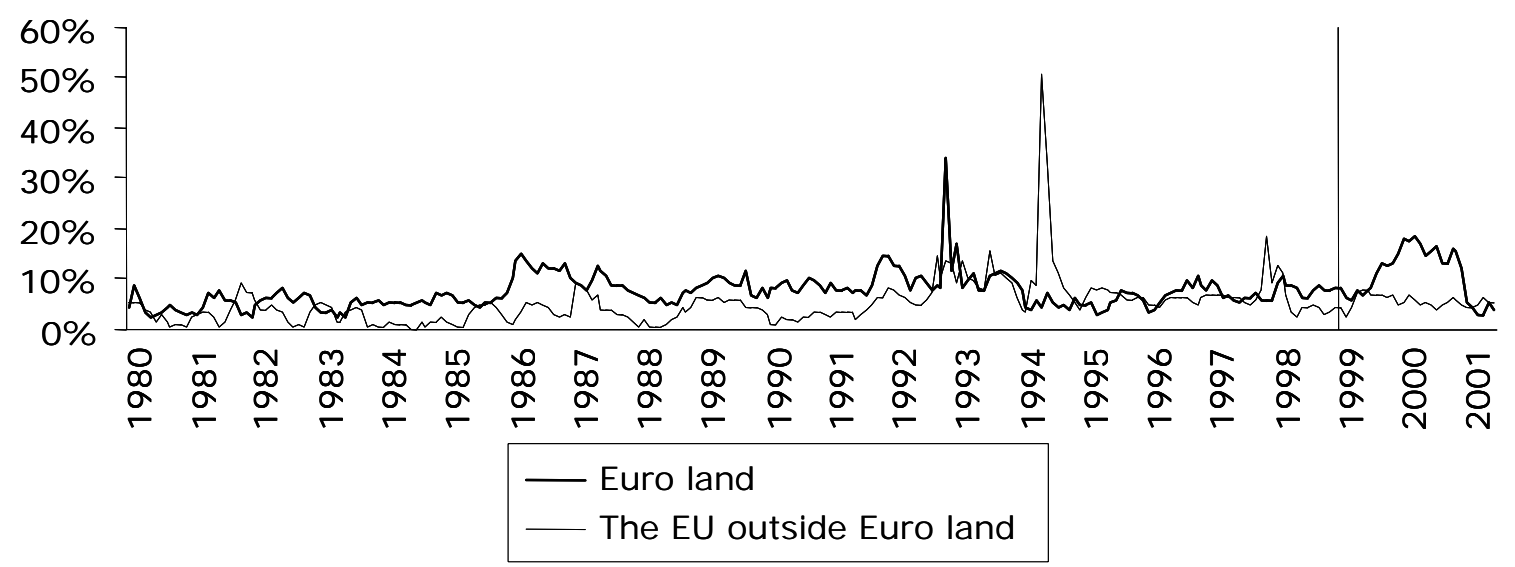

The diagram shows differences between highest and lowest real three-month interest rates for each month over January 1980 to June 2001 for two groups of countries: Euro land and the rest of the EU. Interest rates are interbank rates for all countries except Belgium and Sweden, where rates on three-month T-bills are used. Inflation in a month is measured by the change in producer prices over the preceding year. The horizontal line marks zero, while the vertical line marks the introduction of the euro. Ireland is included from January 1984, Portugal from January 1986, Denmark and Finland from January 1987, Austria from June 1989, Luxembourg from January 1990, and Greece from March 1994. Sources: own calculations, International Financial Statistics, OECD Statistical Compendium, and OECD Main economic Indicators.

The spread between highest and lowest short-term real interest rates in Euro land was fairly stable during the entire period, with only a few exceptions. During 1986 and 1987 the spread increased following increased spreads in producer-price inflation but unchanged nominal interest rates. During the ERM crisis the spread also increased due to some countries increasing their nominal interest rates to defend their fixed exchange rates. After the introduction of the euro the spread increased again, and reached its highest levels of the entire period, November 1992 (the midst of the ERM crisis) disregarded. After the introduction the interbank markets in the currencies of the EMU members disappeared to be replaced by trade in euros. This resulted in interbank rates in the entire Euro land being the same while, as we already have seen, producer-price inflation diverged. The large gap in real interest rates in Euro land following the introduction of the euro was to a large part an effect of the high inflation rates in Portugal. 
The rest of the EU only consists of Sweden and the UK until 1987, and these countries had similar real interest rates. From 1987 Denmark is included in the diagram, but Denmark did not differ much from the other two. The spread in real interest rates among these countries was low until the ERM crisis and then increased. After Greece was included in the diagram, from March 1994, the spread increased again. The spread decreased before the introduction of the euro and then remained small.

Figure 6 shows developments in differences between highest and lowest long-term real interest rates in Euro land and the rest of the EU for the period January 1960 to June 2001. The spread between highest and lowest long-term real interest rate in Euro land remained stable over most of the period. Some periods deviate, however. During the late 1960s the spread increased following low inflation in the Netherlands and high in France. During the 1970s the variations in real interest rates were large, which at times resulted in large spreads in real interest rates. This pattern mirrors the large spreads in inflation during the decade. In the first half of the 1980s the spread in real interest rates increased again, and once again primarily as a result of increasing spreads in inflation. The ERM crisis did not affect longterm real interest rates much. After the introduction of the euro the spread in nominal interest rates was reduced, whereas the spread in inflation increased. This resulted, just as for the short-term real interest rates, in an increased spread in long-term real interest rates. 


\section{Figure 6 Differences between highest and lowest long-term real interest rates, January 1960 to June 2001}

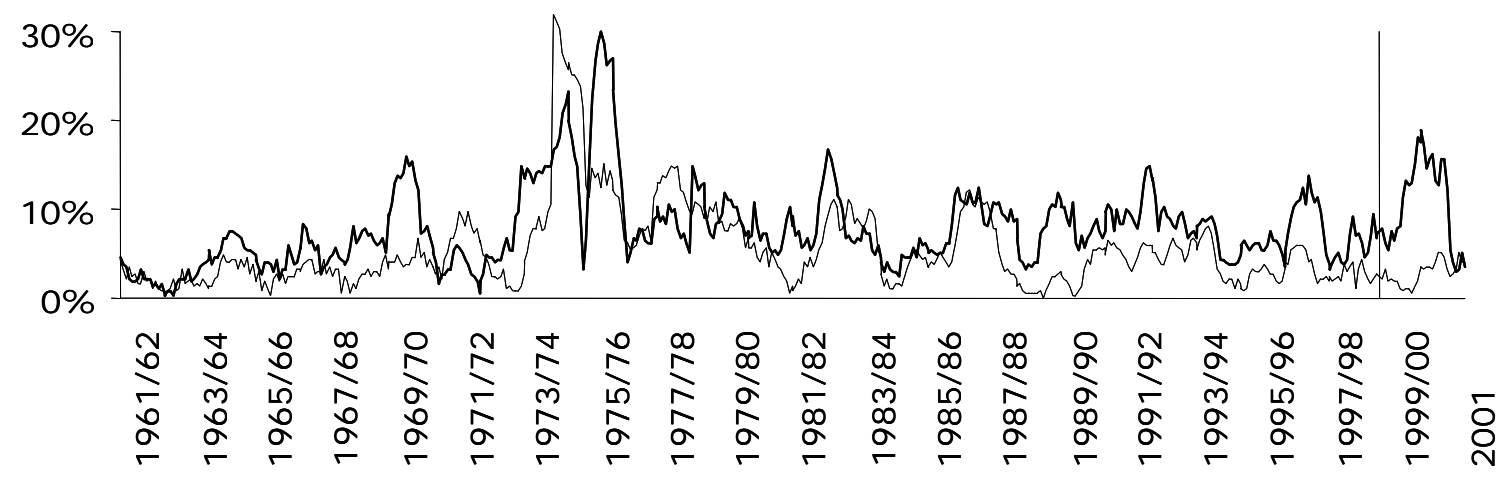

- Euro land The EU outside Euro land

The diagram shows differences between highest and lowest real government bond yields for each month over January 1960 to June 2001 for two groups of countries: Euro land and the rest of the EU. Inflation in a month is measured by the change in producer prices over the preceding year. The horizontal line marks zero, while the vertical line marks the introduction of the euro. Ireland is included from January 1964, Austria from November 1964, Spain from March 1978, Belgium and Luxembourg from January 1981, Italy from January 1982, Finland from January 1988, Portugal from January 1991, and Greece from May 1997. Sources: own calculations, International Financial Statistics, OECD Statistical Compendium, and OECD Main economic Indicators.

The developments in real interest rates in the rest of the EU have been more homogenous than in Euro land. Just as for Euro land, the spread increased during the 1970s and the first half of the 1980s. Prior to the introduction of the euro the spread decreased and then remained low after the introduction.

Table 1 summarizes the average spreads in real and nominal interest rates and inflation for Euro land and the rest of the EU (excluding Greece) in the five time periods mentioned previously. The table shows that the spread in both short- and long-term real interest rates in Euro land increased markedly after the introduction of the euro. The spread in short-term real interest rates reached record highs as compared to the 1980s and 1990s. The spread in longterm real interest rates was almost as high as after the breakdown of the Bretton Woods agreement. 
Table 1 Average spread in real and nominal interest rates and inflation

\begin{tabular}{|c|c|c|c|c|c|}
\hline \multirow[t]{2}{*}{ Period } & \multicolumn{2}{|c|}{$\begin{array}{c}\text { Average spread between } \\
\text { highest and lowest real } \\
\text { interest rates }\end{array}$} & \multicolumn{2}{|c|}{$\begin{array}{c}\text { Average spread between } \\
\text { highest and lowest nominal } \\
\text { interest rates }\end{array}$} & \multirow{2}{*}{$\begin{array}{c}\text { Average } \\
\text { spread } \\
\text { between } \\
\text { highest and } \\
\text { lowest } \\
\text { inflation }\end{array}$} \\
\hline & $\begin{array}{l}\text { Short-term } \\
\text { rates }\end{array}$ & $\begin{array}{l}\text { Long-term } \\
\text { rates }\end{array}$ & $\begin{array}{l}\text { Short-term } \\
\text { rates }\end{array}$ & $\begin{array}{l}\text { Long-term } \\
\text { rates }\end{array}$ & \\
\hline \multicolumn{6}{|l|}{ Euro land } \\
\hline $1961: 1-1971: 7$ & & $5,3 \%$ & & $2,9 \%$ & $7,8 \%$ \\
\hline $1973: 4-1979: 6$ & & $13,9 \%$ & & $8,1 \%$ & $19,8 \%$ \\
\hline $1979: 7-1992: 8$ & $7,4 \%$ & $7,8 \%$ & $10,2 \%$ & $10,4 \%$ & $9,3 \%$ \\
\hline $1994: 1-1998: 12$ & $6,6 \%$ & $6,6 \%$ & $4,9 \%$ & $4,1 \%$ & $7,6 \%$ \\
\hline $1999: 1-2001: 6$ & $10,9 \%$ & $12,1 \%$ & $0,0 \%$ & $0,7 \%$ & $13,8 \%$ \\
\hline \multicolumn{6}{|c|}{ EU outside Euro land (excluding Greece) } \\
\hline $1961: 1-1971: 7$ & & $2,8 \%$ & & $2,1 \%$ & $3,8 \%$ \\
\hline $1973: 4-1979: 6$ & & $13,7 \%$ & & $6,2 \%$ & $13,4 \%$ \\
\hline $1979: 7-1992: 8$ & $3,5 \%$ & $5,0 \%$ & $2,6 \%$ & $3,7 \%$ & $13,8 \%$ \\
\hline 1994:1 - 1998:12 & $3,3 \%$ & $2,8 \%$ & $2,8 \%$ & $1,4 \%$ & $5,3 \%$ \\
\hline $1999: 1-2001: 6$ & $4,1 \%$ & $1,8 \%$ & $2,1 \%$ & $0,7 \%$ & $4,9 \%$ \\
\hline
\end{tabular}

The average spread for interest rates is measured as the average difference between highest and lowest real and nominal, short-term (interbank) and long-term (government-bond) interest rates over each of the five periods. The average spread for inflation is measured as the average difference between highest and lowest annual producer-price changes over each of the periods. Greece is excluded due to lack of interest rates for most of the periods. The time periods used are January 1961 to July 1971 (from the introduction of full currency convertibility in Central and Western Europe to the abandoning of the gold standard), April 1973 to June 1979 (from the breakdown of the Bretton Woods agreement to the introduction of the EMS), July 1979 to August 1992 (from the introduction of the EMS to the ERM crisis), January 1994 to December 1998 (the convergence period), and January 1999 to June 2001. Sources: own calculations, International Financial Statistics, OECD Statistical Compendium, and OECD Main economic Indicators.

In the rest of the EU, Greece omitted, the situation after the introduction of the euro was completely different. The spread between highest and lowest real interest rates increased marginally compared to the 1980 s and 1990 s, whereas the spread in long-term real interest rate decreased. The truth of the matter is that the spread in long-term real interest rates have been at a record low for the EU countries outside Euro land since the introduction and even lower than during the 1960 s. 


\section{The importance of the euro to competition in the $\mathbf{E U}$}

After the introduction of the euro, nominal exchange rates in Euro land converged by definition. This does not mean that exchange rates stopped moving in Euro land, however, since real exchange rates still can fluctuate and give rise to exchange-rate driven changes in competitiveness. The same reasoning holds for interest rates; nominal interest rates have almost converged completely, but real interest rates still deviate thereby causing interest-rate driven changes in competitiveness. We have investigated how real exchange and interest rates have behaved after the introduction of the euro relative to their behavior prior to the introduction. In short, our results show that there are many periods prior to the introduction of the euro when the gap between real exchange and interest rates have been smaller than they were after the introduction.

When nominal exchange rates were fixed, changes in real exchange rates turned into a question of the developments of relative inflation rates. After the introduction of the euro we have observed divergence in terms of a spread between French and Portuguese real exchange rates that has only been surpassed in $13 \%$ of all 30 -month periods since 1960 . After the introduction of the euro, differences between short- and long-term real interest rates in Euro land have increased. Differences in real interest rates in Euro land after the introduction have in fact been record high as compared to the 1980 to 1998 period. Differences in real interest rates are almost as large as just after the breakdown of the Bretton Woods agreement.

The developments after the introduction for those EU countries that do not belong to the EMU partly resemble those of Euro land. The divergence is not as strong, however, and spreads not as large. As regards differences among long-term real interest rates in those EU countries outside the EMU, developments are more divergent; differences have been record low since the introduction of the euro and even smaller than differences during the 1960s. 
Our analysis thus indicates that the introduction of the euro, at least during the first 30 months after the introduction, has not contributed to an elimination of macroeconomically driven changes in competitiveness. We cannot even see a clear reduction when compared to a longer period. It seems that the fixing of nominal exchange rates have "spilled over" in real exchange and interest rates through increased divergence in inflation in producer prices.

Our study does not answer the question how this increased divergence in producer-price inflation arose. This is a topic for further research. One tentative explanation could be that our assumption that real exchange rates were at parity prior to the introduction of the euro is not correct. The divergences we see could be a result of a correction of the real valuations of the euro currencies. That would mean that the Portuguese escudo was in fact undervalued by $30 \%$ relative to the French franc when the euro was introduced. It seems unreasonable, though, that Portugal received the favor of an undervalued currency when the irrevocable conversion rates were set. It should also be noted that Portugal is not the only country that have created divergence after the introduction of the euro. Another tentative explanation could be that those price levels that prevailed before the introduction were not sustainable, that is, in particular state-owned companies kept prices artificially low to increase chances of an EMU membership.

In the best of worlds the limited increases in consumer prices in combination with large producer-price increases in certain countries could lead to a restructuring of the manufacturing sector in Euro land. That would increase the competitiveness of Euro land visà-vis the US. The problem is that this process in slow and painful. Portuguese companies for instance face the risk of pricing themselves out of the market. Sticky wages and low levels of labor mobility, which are well-known problems in Euro land, would mean that restructuring causes unemployment, in particular in the most affected countries. On the bright side, the pains of restructuring are partly mitigated by the low - or negative - real interest rates that are 
a consequence of high inflation in certain countries combined with nominal interest rates converging in Euro land.

There is a risk that granting of structural support to the most affected countries or industries hinders the restructuring. There is also a risk of increasing competition in Euro land for inward direct investments through social dumping and tax exemptions (Oxelheim, 1993). If these risks are not fulfilled, there is a good side to the problems that follow from increased inflation and increasing divergence, since restructuring will be accelerated. So far, however, there are no indications that any restructuring has taken place; hourly compensation costs have not converged, as they would have if productivity had increased to close the gap.

A further topic for future research is the assessment of the gravity of the developments we have seen. How large price gaps are sustainable under a single currency? Comparisons with the US could provide an answer. If price gaps are larger among countries in Euro land than among states in the US, Euro land with its markedly lower cross-border labor mobility will face difficulties.

A prerequisite for a successful monetary union is that differences in economic developments are eliminated to avoid threats to the stability of the union. Our results indicate an ominous risk that such differences are not eliminated. On the contrary, there is a risk that differences are aggravated, since monetary policy is focused on convergence in consumer prices. This risk is latent in the lack of convergence of those macroeconomic variables that are relevant to competitiveness. The implication of our results to policy on the EMU level is that this risk should be moderated with better control over inflation as measured by a wider price index that the consumer price index. On the company level, our results imply that exchangeand interest-rate driven changes in competitiveness will conceal requirements for product and process developments inside Euro land, just as they did prior to the introduction of the euro. 


\section{References}

Andrén, N (2001), "Essays on Corporate Exposure to Macroeconomic Risk", Lund Studies in Economics and Management 62, Lund: Lund Business Press.

Baldwin, R (1989), ”On the Growth Effects of 1992”, Economic Policy 9, 248-281.

Baldwin, R (1991), "On the Microeconomics of the European Monetary Union”, European Economy 44, 19-35.

Beyer, A, J A Doornik, and D F Hendry (2001), 'Reconstructing Aggregate Euro-Zone Data", Journal of Common Market Studies 38, 613-624.

Eichengreen, B (2000), 'The Euro One Year On”, Journal of Policy Modeling 22, 355-368.

Ekström, J (1998), "Foreign Direct Investment by Large Swedish Firms - the Role of Economic Integration and Exchange Rates", Lund Studies in Economics and Management 41, Lund: Lund Business Press.

Emerson, M, (1988), The Economics of 1992, Oxford: Oxford University Press.

European Central Bank (2000), Convergence Report 2000, Frankfurt.

European Commission (1996), The 1996 Single Market Review, Brussels.

European Commission (1999), "Economic Reform: Report on the Functioning of Community Product and Capital Markets”, Brussels.

European Commission (2001), "EMU: The First Two Years", Euro Papers No 42, Brussels. European Monetary Institute (1998), Convergence Report, Frankfurt.

Feldstein, M (2000), 'The European Central Bank and the Euro: The First Year", Journal of Policy Modeling 22, 345-354.

Goldberg, P K and M M Knetter (1997), “Goods Prices and Exchange Rates: What Have We Learned?", Journal of Economic Literature 35, 1243-1272.

Gros, D and N Thygesen (1998), European Monetary Integration, Harlow, England: Prentice Hall. 
Knetter, M M (1993), “International Comparisons of Pricing-to-Market Behavior”, American Economic Review 83, 473-486.

Oxelheim, L (1993), "Foreign Direct Investment and the Liberalization of Capital Movements", in L Oxelheim (ed), The Global Race For Foreign Direct Investment. Prospects for the Future, Heidelberg: Springer.

Oxelheim L (1996), Financial Markets in Transition - Globalization, Investment and Economic Growth, London: Routledge. 